\title{
Reserves of teaching staff's productivity growth based on lean technologies
}

\author{
Alena Alexandrovna Borisova ${ }^{1}$, Victoria Alexandrovna Vinichenko $^{1,2^{*}}$, Ekaterina \\ Vladimirovna Spiridonova ${ }^{1}$, and Elena Nikolaevna Kirichenko ${ }^{3}$ \\ ${ }^{1}$ Novosibirsk State Technical University, Management Department, Novosibirsk, Russia \\ ${ }^{2}$ Siberian State University of Water Transport, Department of Transport Economics and Finance, \\ Novosibirsk, Russia \\ ${ }^{3}$ Novosibirsk State Technical University, Department of Foreign Languages, Novosibirsk, Russia
}

\begin{abstract}
The purpose of this study is to find and justify reserves for increasing the productivity of teachers on the example of the Novosibirsk State Technical University. Some of the methods presented in the paper are well-known and are of interest from a practical point of view. These include a survey, observation, experiment, and in-depth interview. Some methods are specific and are more often used by experts in the field of lean manufacturing. The key set of lean tools was the kaizen umbrella, which includes the philosophy of continuous improvement, the method of mapping the value stream, the "five why" method. Diagrams of various purposes are widely used in the article: Ishikawa, Pareto, spaghetti. The main problem solved in this paper is a large number of errors in syllabuses, a long time of their creation and excessive control. The hypothesis about the simultaneous elimination of these shortcomings by automating the process itself was tested. The experiment proved the validity of the hypothesis. The duration of the value creation process during the development of syllabuses was reduced by $15 \%$, and the overall satisfaction of the participants in the process increased by $27.5 \%$. The total savings of the working time fund amounted to 0.5 million man-hours across the entire university, accounting for almost 100 thousand syllabuses. Keywords: lean manufacturing, labor productivity, syllabuses, automation of the process
\end{abstract}

\section{$1 \quad$ Introduction}

The steady interest of business in the search and improvement of management tools is explained by the need to ensure the competitive advantages of the company. The ways of increasing competitive advantages are differentiated and will be actively expanded: diversification [1], speed, focus orientation, technologies, innovations [2], as well as rational use of limited resources [3]. Methods of ensuring competitive advantages are implemented in two directions: external, aimed at finding the best business practices in

\footnotetext{
*Corresponding author: vika_06.07@mail.ru
} 
comparison with competitors, and internal, involving the search for reserves within the company itself.

The search and updating of the company's internal reserves is implemented in the concept of rational business management and the introduction of lean technologies. The concept of lean technologies appeared due to the founders of practice-oriented regular management (A. Gasteva [4], P. Kerzhentseva [5], T. Ono [6] and was tested on empirical objects - complex production systems. Until now, manufacturing companies prevail in terms of the frequency of implementing lean technologies. Eliminating irrational losses and setting up a balanced system of regular improvements provide a significant increase in labor productivity. After manufacturing enterprises, trade organizations and institutions of the service sector (healthcare [7], transportation carriers [8] and education [9]) joined. Federal programs are being created to support companies that implement measures to update internal reserves, as well as associations that accumulate and promote the practice of regular process improvements.

In general, we can note an increase in the number of followers of the concept of lean thinking and the search for internal reserves of development. But the involvement of a larger number of Russian participants is slower compared to non-CIS countries [10]. Therefore, it is relevant to request proof of the effectiveness of the system of lean and rational organization of activities, as well as an assessment of the effectiveness of the transfer of lean tools from the production sector to others [11]. The availability of such evidence can contribute to the spread of the practice.

The purpose of this study is to test a set of lean production tools for a specific field-education - and to substantiate the possibility of improving (efficiency) the implementation of the current process based on the application of the concept of "lean thinking".

The choice of the object of observation - the organization of the educational process is due to several arguments:

firstly, the education sector is at the stage of active testing of changing formats for organizing activities and the educational process. This stage is resource-intensive and requires the search for internal resources to eliminate inefficient activities and operations;

secondly, regular changes in the field of education have led to an increase in the measures of resistance and protection of personnel, as well as to the underutilization of professional and qualification potential. It is possible to increase the index of trust and loyalty of personnel to the management system and the decisions initiated by it on the basis of evidence-based experiments of participants' benefits. Therefore, the implementation of a real project with the justification of the increase in improvements and leveling the problems of the labor subject contributes to reducing resistance to changes and increasing confidence in the management system;

thirdly, positive results can be replicated to a sufficiently large number of institutions, since the regulatory system is set up.

Therefore, it is necessary to test the technology and its instrumental support for educational institutions.

The achievement of the research goal indicated the fulfillment of a number of tasks:

- substantiation of the prerequisites for the need to regulate the implementation of the educational process on the example of a single element - development and updating of curriculums;

- identification and analysis of sources of process losses;

- selection and justification of a set of lean production tools necessary for the implementation of the improvement project; 
- evaluation of the effectiveness of the implementation of the improvement project and justification of the impact of the used tools.

Such an organization of the research will allow: first to justify the need to regulate the current organization of the educational process and to digitalize the problems factually (to fix the state as it is); then to develop and implement an improvement project that includes a set of lean production tools and determine the necessary resource support for its implementation (experiment) and finally, to assess the effectiveness of the changes introduced (to characterize the state as it has become).

\section{$2 \quad$ Materials and methods}

The logic of achieving the set research goal indicated the choice of research methods. The experiment was chosen as the main method of proving and evaluating the effectiveness of the use of lean production technologies.

For the experiment, one element of the educational process was selected, that is the preparation and updating of curriculums by teachers. Criteria for selecting a process element are as follows: high labor intensity of work on the process and the interest of participants in reducing labor costs, as well as the possibility of introducing instrumental solutions into the process of regulating the process.

The subjects of observation were the direct participants of the process. Initially, the analysis of the studied process was carried out by the method of observation, questionnaires and in-depth interviews. The assessment of the types of losses identified during the experiment was carried out according to the traditional classification proposed by Tahiti Ono [12]. To process the received information material, both traditional methods of analysis and specific methods typical for the implementation of projects for the implementation of improvements using lean technologies were used. The selection criteria are related to the frequency and prevalence of tools in the business environment. The arsenal of tools includes mapping the flow of value creation, the method of highlighting problems and their analysis. The root causes were determined by constructing an Ishikawa diagram [13]. The Pareto diagram was used to select the root causes that affect the occurrence of the identified problems. Confirmation of the objectivity of the analysis was carried out by the "five why?" method, which was used in relation to the heads of departments and directly participants in the process.

After selecting the key problems, a pool of recommendations was formed to eliminate them. The expert assessment made it possible to exclude difficult to perform or difficult to achieve tools, focusing on those that can form a mechanism for increasing the productivity of the teaching staff in the foreseeable future. The chosen solution did not require significant investments and at the same time, it allowed to eliminate several types of losses at the same time.

Then a project group was formed and a roadmap for the implementation of the experiment was drawn up. Finally, after a while, the research team characterized and evaluated the results of the experiment.

\section{$3 \quad$ Results}

The key reasons that significantly determine the need to initiate this experiment were the low level of satisfaction with the speed and quality of the process of creating work programs of the discipline. The assessment of the level was carried out by interviewing 
participants. 175 people were interviewed, including heads of structural divisions performing supervisory functions in the process. The survey results are shown in Figure 1.

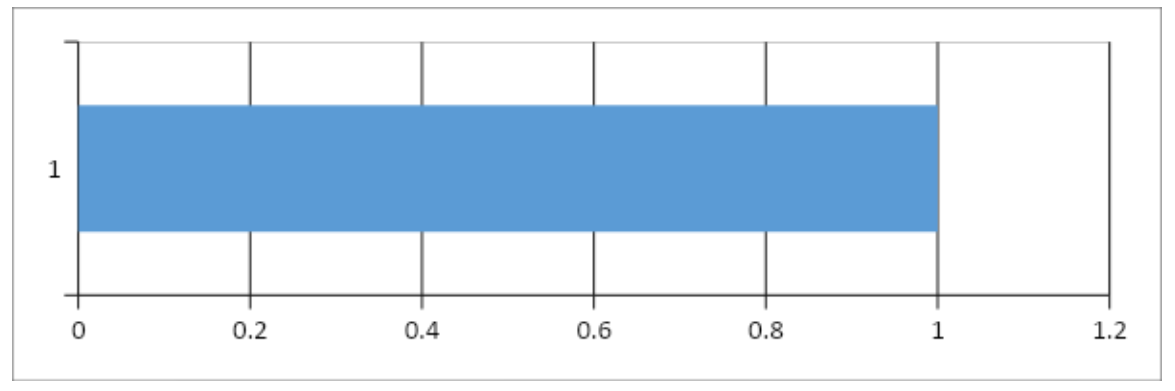

Fig. 1. The level of satisfaction of the participants in the process. Source: compiled by the authors.

The lowest level of satisfaction was revealed by the parameters "duration" and "organization of the process". The same conclusion was confirmed by the results obtained when constructing the Pareto diagram (Fig. 2)

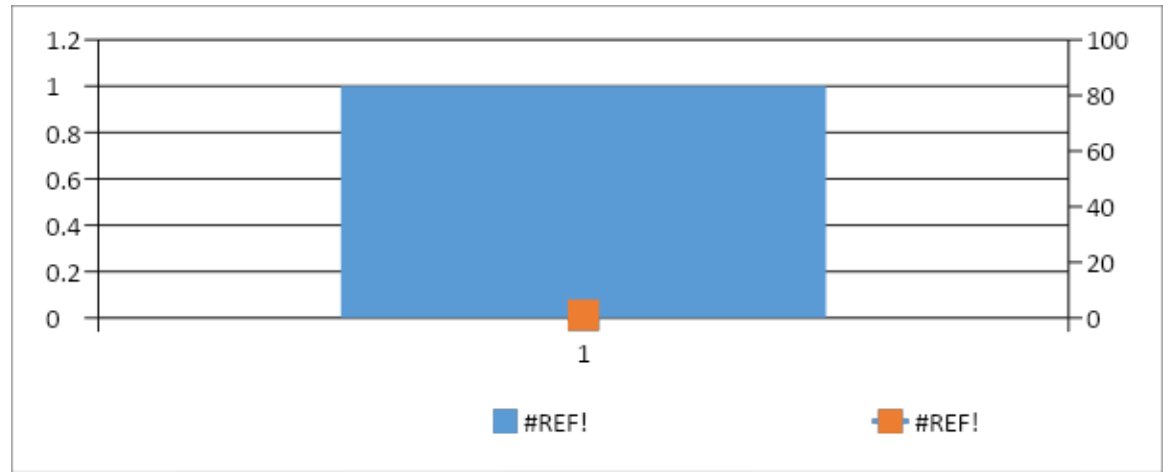

Fig. 2. The Pareto diagram to identify the root causes of the poor quality of the process of creating work programs. Source: compiled by the authors.

Based on the analysis of the Pareto diagram, the most significant losses were a high level of expectation and frequent defects in the work. Focusing on the received losses allowed us to determine which of them are of the greatest interest from the point of view of optimizing the analyzed process (Table 1).

Table 1. Analysis and diagnosis of problems. Source: compiled by the authors.

\begin{tabular}{|c|c|c|}
\hline Type of loss & The key reason & $\begin{array}{c}\text { Direction of measures to } \\
\text { eliminate }\end{array}$ \\
\hline Overproduction & $\begin{array}{l}\text { The difficulty in signing the title pages, as } \\
\text { there are often no managers on the ground }\end{array}$ & \multirow{3}{*}{$\begin{array}{l}\text { Unification of the electronic } \\
\text { template with the inability to } \\
\text { correct and include } \\
\text { information from the General } \\
\text { description of the educational } \\
\text { program }\end{array}$} \\
\hline Stocks & $\begin{array}{c}\text { A large number of errors and a frequent need } \\
\text { for reprinting the Syllabus }\end{array}$ & \\
\hline $\begin{array}{l}\text { Unnecessary } \\
\text { processing }\end{array}$ & $\begin{array}{l}\text { The template can be changed by the } \\
\text { performer, different versions automatically } \\
\text { transform the document }\end{array}$ & \\
\hline Expectation & $\begin{array}{l}\text { There is no automatic notification of } \\
\text { receiving a document on the table. Often you } \\
\text { have to call, write and visit several times }\end{array}$ & $\begin{array}{l}\text { Automatic pull-up of } \\
\text { information from databases }\end{array}$ \\
\hline
\end{tabular}




\begin{tabular}{|c|c|c|}
\hline $\begin{array}{l}\text { Unnecessary } \\
\text { movements }\end{array}$ & \multirow{2}{*}{$\begin{array}{l}\text { Duration of the process of physical } \\
\text { movement of information }\end{array}$} & \\
\hline $\begin{array}{l}\text { Unnecessary } \\
\text { transportation }\end{array}$ & & \\
\hline Some reject & The human factor & \multirow[b]{2}{*}{$\begin{array}{l}\text { Creating internal control at all } \\
\text { stages of syllabus development }\end{array}$} \\
\hline $\begin{array}{l}\text { Unrealized human } \\
\text { potential }\end{array}$ & $\begin{array}{l}\text { Excessive control at several stages leads to } \\
\text { an irrational distribution of potential }\end{array}$ & \\
\hline
\end{tabular}

In most cases, there was a human factor, since the program template was easily changed the teacher working in it can happen to make spelling and punctuation errors. The hours periodically did not coincide with those specified in the curricula. The duration of the process was increased by additional control (often unnecessary). However, the further down the value stream the error was discovered, the more the process was delayed. Sometimes the error occurred already in the process of placing the agreed program on the site. Thus, it was necessary to completely go through the entire procedure again.

If we structure the key reasons that cause losses, we can talk about the existence of three key areas of countering these causes - automation of the process, unification of the template with the impossibility of changing it, and quality built into the process.

As a result of the experiment, it was decided to create a software product that allows you to automatically create syllabuses and build the necessary connections with the requirements of educational and professional standards.

The created system allowed to build the process in the personal account, access to which was provided by login and password in the electronic information educational environment of the teacher. The duration of the process of creating a syllabus was reduced by 227 minutes (from 1558 minutes), and the number of errors per syllabus was 1 (instead of 9 previously noted).

The process has been significantly simplified by embedding quality in it. The system did not allow the teacher to specify irrelevant data, since it synchronized several databases simultaneously. Thus, databases were created with up-to-date sources of educational, methodological and scientific literature (electronic library system), which compiled a list of 8279 titles. An additional database was created using software, which the teachers indicated in the work programs when describing the material and technical equipment of the educational process. The database on the teaching staff included about 1.5 thousand teachers. In total, the system made it possible to integrate syllabuses in more than 180 specialties (areas of training). Currently, the software contains about 100 thousand syllabuses only for full-time training.

A repeated survey of the participants in the process showed that the overall increase in satisfaction was almost 30\% (Figure 3).

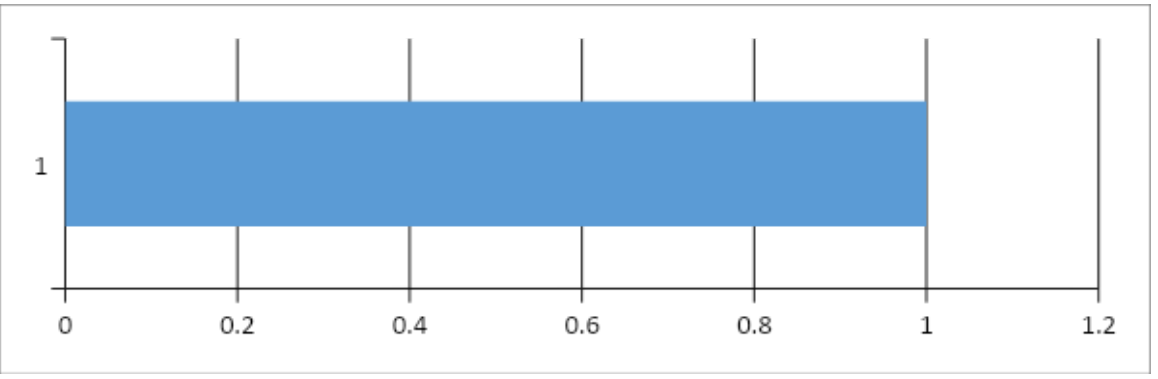


Fig. 3. The level of satisfaction of the participants in the process after the transformations. Source: compiled by the authors.

The total savings of the working time fund amounted to almost 0.5 million man-hours during the preparation of syllabuses for one period. The map of the value creation flow is not presented in this paper due to the limited amount of information available for placement. However, it should be noted that during the mapping process, the number of participants decreased from 7 to 3 , and the total number of touch points of the process decreased by $37 \%$. Control functions were integrated into the system, thus removing the burden of verification from the heads of departments, deans and educational management.

\section{Discussion}

The inclusion of software in the electronic educational environment allows you to strengthen several bottlenecks of the process at the same time. Facilitating the process of creating syllabuses in general increases the motivation of the teacher. The creation of a syllabus is considered routine work and teachers often boycott this process. The head of the structural unit has to shift this responsibility to a less qualified employee who does not deliver the discipline (for example, an assistant of the department), which leads to a formal approach to performing the task of methodological support of the discipline. Automation allows the teacher not to be distracted by technical issues and fill the program cells exclusively with meaningful content that is directly related to the discipline being taught. The embedded templates (for example, the type and form of classes) set the teacher a vector of the educational process that does not contradict the requirements of educational standards, which takes into account the interests of the modern labor market (for example, the content of competencies).

\section{Conclusion}

According to the lean production methodology, the key losses were identified within the framework of the project under consideration - some reject, expectation, unnecessary movements. The developed software product was focused on their minimization. The results obtained made it possible to significantly reduce the cycle time for preparing syllabuses and increase the satisfaction of the participants in the process. At the same time, lean production involves building a system of continuous improvements.

The first direction of improving the project is the context menu (pop-up windows with hints). The survey of the participants of the process both before and after the introduction of the software product revealed that the quality of support and service is one of the bottlenecks in the process of preparing syllabuses.

The second area of improvement is the spell checking module. One of the main losses in the process was some reject. The implemented program allowed to reduce the average number of errors in the program from 9 to 1 . The main attention was paid to the moments that violate the restrictions of external (federal) and intra-university standards. Along with these fundamental deviations, spelling and punctuation errors were also detected, which are not yet controlled in the author's texts.

The third direction is timely interaction with customers. When building a value stream map, external users were identified as the main customers of syllabuses: students, applicants, employers. Employers are interested in ensuring that graduates master all the 
necessary competencies, receive the required knowledge and skills. In this regard, when preparing syllabus of specialized disciplines, a dialogue with the employer is extremely important. The remote format of interaction will reduce the losses when organizing this dialogue. The prepared (corrected) syllabus should be automatically placed on the site so that users can see its current version. Thus, the modules "examination by the employer" and "automatic upload to the site" are the third additional step.

The planned directions for improving the software product require additional resources, but it seems that they will be able to significantly increase the value of the product for the consumer.

The research was carried out with financial support within the framework of the NSTU development program, scientific project No. C21-20.

\section{References}

1. L.L. Klein, M.S. Tonetto, L.V. Avila, R. Moreira, J Cleaner Prod, 286, 125386 (2021). https://doi.org/https://doi.org/10.1016/j.jclepro.2020.125386

2. C. Tasdemir, K. Gazo, J Cleaner Prod, 265, 121759 (2020). https://doi.org/10.1016/j.jclepro.2020.1217590959-6526

3. K. Marx, Kapital. K kritike politicheskoi ekonomii. Pervyi tom. Protsess proizvodstva kapitala. Pervyi razdel. Tovary i dengi. Pervaya glava. Tovary [Capital. To the criticism of political economy. First volume. The process of production of capital. First section. Goods and money. First chapter. Goods] (Book laboratory, Lenizdat, 2018)

4. A.K. Gastev, Model Philosophical Encyclopedia. 3. V (Moscow, 1964)

5. A.J.H. Enthoven, J.V. Sokolov Accounting Practices and Education in Russia and Other Republics of the C.I.S., in J.O. Burns, B.E. Needles (eds), Accounting Education for the 21 st Century, Pergamon, 35-41 (1994). https://doi.org/10.1016/B978-0-08-042405-7.50010-1

6. R. Shah, P.T. Ward, J Oper Manag, 25(4), 785-805 (2007). https://doi.org/10.1016/j.jom.2007.01.019

7. D. Paul-Eric, P. Rafael, S. Cristiane., Ch.Jr Joao, Procedia Manuf, 51, 1657-1664 (2020). https://doi.org/10.1016/j.promfg.2020.10.231

8. B. Villarreal, J.A. Garza-Reyes, V. Kumar, M.K. Lim, Int J Logist, 20(2), 163-180 (2017). https://doi.org/10.1080/13675567.2016.1170773

9. N. Sremcev, et al., Procedia Manuf, 17, 595-602 (2018). https://doi.org/10.1016/j.promfg.2018.10.101

10. J.K. Liker, J.M. Morgan, Acad Manag Perspect, 20(2), 5-20 (2006)

11. S. Zargun, A. Al-Ashaab, Adv Mater Res, 845, 668-681 (2013). https://doi.org/10.4028/www.scientific.net/AMR.845.668

12. M. Holweg, J Oper Manag, 25(2), 420-437 (2007). https://doi.org/10.1016/j.jom.2006.04.001

13. T. Varzakas, HACCP and ISO22000: Risk Assessment in Conjunction with Other Food Safety Tools Such as FMEA, Ishikawa Diagrams and Pareto, in B. Caballero, P.M. Finglas, F. Toldrá (eds), Encyclopedia of Food and Health, 295-302 (Academic Press, 2016). https://doi.org/10.1016/B978-0-12-384947-2.00320-2 